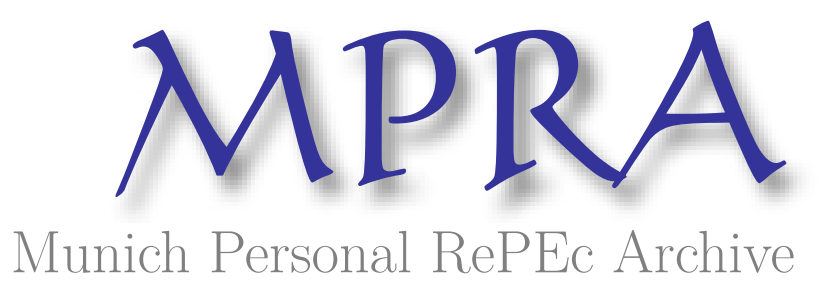

\title{
Institutional Laws, and Mergers and Acquisitions in India: A Review/Recommendation
}

Reddy, K. Srinivasa

Independent Researcher

2015

Online at https://mpra.ub.uni-muenchen.de/63410/

MPRA Paper No. 63410, posted 04 Apr 2015 06:06 UTC 
Institutional Laws, and Mergers and Acquisitions in India: A

\title{
Review/Recommendation
}

\author{
K. Srinivasa Reddy \\ Independent Researcher, India. \\ E-mail: cssrinivasareddy@gmail.com
}

Paper in Progress

2015

(C) K. Srinivasa Reddy, 2015 


\title{
Institutional Laws, and Mergers and Acquisitions in India: A Review/Recommendation
}

\begin{abstract}
The paper intends to review, summarize and discuss various institutional laws refer to mergers and acquisitions (M\&A) in India, and thereby recommend fruitful policy guidelines for institutions and managers participating in foreign investment and acquisition deals. Further, we also show the market for value of foreign inbound and outbound deals representing India for the period 2004 through 2013. The major observations include, higher valuation inbound-deals had delayed or failed due to weak financial infrastructure, erratic nature of government officials and political intervention, and the newly elected government has aimed to attract higher inflow of investment from other developed and emerging markets by easing investment rules and offering tax holidays. The study eventually would help policy makers, M\&A advisors, legal consultants and investment bankers in assorted issues, and private equity firms and multinational firms intending to invest in Indian business.
\end{abstract}

Keywords: Acquisitions \& mergers; Financial laws; India; International business; Takeovers; Emerging markets; Foreign direct investment.

\section{Introduction}

It is worth highlighting that the 1980's economic policy reforms have initiated across the world, where in, the idea of "economic deregulation, financial liberalization and national integration" engulfed from developed economies institutions to developing countries. Consequently, a number of developing countries have noticed a significant growth in international trade and capital flows, foreign exchange reserves, technological transformation and development of local businesses, among others. For example, major Asian, African and Latin American countries have emphasized in education, health, foreign investment, capital markets, consumption, regulation, and institutional and entrepreneurship development (Akbulut and Matsusaka, 2010; Cheng et al., 2007). On the other hand, a number of economic researchers have noticed a substantial growth in the market for inward direct investment curving from developed markets to emerging markets due to easing of foreign direct investment policies. As a result, business enterprises have gained access to wider markets with their varieties of products and services (Alguacil et al., 2011; OECD, 2009). 
Thus, emerging markets, Brazil, Russia, India, China (BRIC), Indonesia, South Africa and others have become important contributors to today's global economy. For instance, the combined output of these markets have accounted for 38\% of world GDP in 2010, twice its share in 1990 (Dhanaraj and Khanna, 2011, p. 684). According to the United Nations Conference on Trade and Development (UNCTAD), the cumulative international direct investment has reached about US\$1,244 billion in 2010, while a significant amount of rise is attributed to high-growth emerging markets (Nagano and Yuan, 2013).

The Asian market was seen a severe economic crisis in 1997, which had high-minded qualms in the securities market (Tan and Hooy, 2003) and the collision of IT bubbles in 2000. Being influenced by the crisis experience, local firms have chosen various corporate inorganic strategies include acquisitions and alliances (as cited in Reddy et al., 2013). Based on previous year's world investment reports, we realize that there is a considerable increase in international investments, where it is being reversed from emerging markets to developed markets. This investment behavior was identified in the aftermath of the 2007-08 global financial crisis due to lower asset valuations, attractive investment and tax policies offered by the host country, and home country institutional constraints with regard to inward overseas investment (Reddy et al., 2014b).

In case of India, mergers, takeovers and other corporate restructuring activities are uncommon prior to the New Industrial Policy reforms-1991(Ahluwalia, 2002; Ray, 2010), later, they occurred due to regulatory shocks (Agarwal and Bhattacharjea, 2006). The actual merger wave was started after 1994 where the necessity of formulating a new takeover code felt by the regulating agencies (Reddy et al., 2011, 2013). ${ }^{1}$ This momentum lucratively changed the business scenario from back-end mapping to front-end strategies, which also motivated consolidation activities. Eventually, global competition has prompted the Indian MNEs to choose M\&A as an important strategic choice for gaining operating and financial synergies. For example, the period 2000-07 has noticed a phenomenal growth in India's outbound M\&A transactions (Varma, 2011). ${ }^{2}$ Herewith, we show the trend of foreign inbound and outbound deals (value, US\$ millions) representing India over the last 10 years, 2004-2013 (Figure 1). By observing this pictorial, one would notice that the value of inbound

\footnotetext{
${ }^{1}$ The first privatization occurred in 1999 , when $74 \%$ of the equity of Modern Foods India Ltd. (a public sector bread-making company) was sold to Hindustan Lever, an Indian subsidiary of the Anglo-Dutch multinational Unilever. Other disinvested public sector enterprises include BALCO, Computer Maintenance Corporation, Hindustan Zinc, IPCL, Maruti Udyog, VSNL, and so forth (Ahluwalia, 2002, p. 84).

${ }^{2}$ Between 2000 and 2007, there were over 521 overseas acquisitions from India out of which 133 (25.5\%) happened in the IT sector; and 12\% of these CB-M\&A deals were done by the firms that are less than five years old at the time of acquisition (Varma, 2011, p. 352).
} 
deals actually not seen a significant capital receipt compare to value of outbound deals. Besides, outbound deals reported high rate of growth in 2007 and 2010 due to global financial crisis and slow down in Euro financial markets. However, outbound deals started declining since 2011, while inbound deals showed progress compare to previous years. We infer that Indian multinational companies (MNCs) had invested in other countries through acquisition route due to lower asset valuations and attractive prices on the account of the economic crisis, but their active participation has descended after 2010. Conversely, foreign multinationals have started investing in India since 2011 because of significant changes in overseas investment policies include new companies bill, incentives and subsidies; this mark is really a good sign for growing economies like India. In the recent past, tax and advisory firm based in India, Grant Thornton has reported that both M\&As and private equity deals amounting to US\$32.6 billion (762 transactions) during January-August, 2014, which is notably higher than previous year records about US\$27.7 billion (614 transactions) due to adequate changes in the legal and political environment (Economic Times, 2014b). Overall, number of deals and value are likely representing upward-trend in the current fiscal period than previous years; particularly relaxation of the acquisition process is one of the incentives behind raising inbound deals.

\section{[Insert Figure 1 here]}

Nobel laureate, Professor Douglass North described that institutions, culture and societal factors influence all business related activities in the given setting due to internal and external shocks (North, 1990). Similarly, it is not a surprising question if a foreign investment proposal receives attention call from host country's government and political roles. For example, a recent study by Czinkota and Skuba (2014) described that differences among countries in legal and regulatory framework play key role in overseas investment decisions due to macro factors such as "system transparency, degree of corruption, adequate enforcement and issues of bias related to foreign-owned firms". In other words, quality of the legal framework, regulatory infrastructure and ruling political party behavior influences the efficiency of the transmission process relating to business negotiations. Acquisitions therefore play an imperative role in accessing resources when the institutional setting is stronger (Meyer et al., 2009). Because of policy reforms, a number of earlier laws and provisions have been demolished and enacted new regulations in many trades (World Bank, 2014, p. 35, 192). Nevertheless, emerging economies like China and India still require 
emphasizing on second-wave deregulation of investment and business rules for efficient and transparent administration and for controlling economic frauds and corruption. Indeed, few emerging market giants have proposed to reconfigure their legal framework thus to attract more investments in infrastructure and other core industries through either acquisition route or direct method (Isa, 2014; Kumar, 2009).

With this backdrop note, the paper aims to review various M\&A laws in India and thereby suggest policy implications for different stakeholders, who involve directly or indirectly in the acquisition process. In particular, we present a set of recommendations for multinational managers participating in acquisition negotiations that especially hosted by emerging markets, and discuss prospects that benefit businesses and society in general.

The remainder of the paper is organized as follows. Section 2 presents M\&A laws in India. Section 3 reports the dichotomous experience of foreign in/out bound deals. Section 4 discusses potential recommendations for policy makers, legal framework and business managers. Section 5 concludes the study.

\section{Institutional and M\&A laws in India}

We present India's M\&A regulatory framework, which comprises six sovereign institutions (Figure 2), namely Companies Act, 1956 (Registrar of Companies under the Ministry of Corporate Affairs), SEBI-SAS\&T Regulations, 1997 (Securities and Exchange Board of India), Competition Act, 2002 (Competition Commission of India), Income Tax Act, 1961 (Department of Revenue), Reserve Bank of India (RBI) and Foreign Investment Promotion Board (FIPB). There are some other acts, which administer directly or indirectly related to domestic and foreign investment deals. For instance, the acts include Transfer of Property Act, 1882; Indian Stamp Act, 1899; Registration Act, 1908; Customs Act, 1962; and Foreign Exchange Management Act, 1999. Most of these regulations are being controlled by the Department of Revenue under the Ministry of Finance (cf. Reddy et al., 2014a). Herewith, we provide a brief notes relating to relevant laws based on the importance of act/governing body.

\section{[Insert Figure 2 here]}

\subsection{Companies Act, 1956}

The existing Companies Act, 1956 was formally enacted by the Parliament. It is one of the important M\&A laws, which deals with the procedural aspects of mergers or amalgamations. 
The act has not been defined what is a merger or acquisition. Hence, it has suggested 'three terms' related to inorganic strategies under Sections 390-396, the terms like "compromise", "arrangement", and "reconstruction". In fact, it uses the term "amalgamation" without defining it clearly (Ray, 2010). For instance, Section 390(a) states, "no company involved in an amalgamation likely to be financially unsound or under winding-up setting. In particular, the Companies (Court) Rules 1959, exhibit various provisions that should be taken care while processing amalgamations through the courts. Section 391 indicates "the High Court (where the registered office of the company is situated) has the power to sanction a "compromise" or "arrangement" between a company and its creditors, Section 392 empowers the court to enforce and supervise such compromises or arrangements, Section 394 makes provision for facilitating the reconstruction and amalgamation of companies by making the appropriate application before the court, Section 395 allows for the acquisition of shares of shareholders dissenting from the scheme or contract which has been approved by the majority, and Section 396 enables the government to provide for an amalgamation of companies in national interest" (Shroff and Ambast, 2013, pp. 89-90). On the other hand, it does not deal when a merger transaction involves 'sick industrial company' as acquirer or target. In addition, "Sections 108A-108F of the act have been mandated that the approval of the central government is necessary for the acquisition of shares by an individual, firm, or corporation where the increased shareholding goes beyond a prescribed value" (Shroff and Ambast, 2013). In 2005, the Irani Committee, 2004 (Chairperson: J.J. Irani, Director of Tata Sons Ltd) has made several recommendations to improve the act, including that there is an urgent need for the law to provide for a single controller, which is required to approve mergers in a specified and time bound manner" (Shroff and Ambast, 2013; Banerjee et al., 2014). Further, new Companies Bill-2012 has updated with significant changes (pre-merger approval) and simplified the process relating to acquisition of smaller companies (Shroff and Ambast, 2013).

\subsection{Competition Act, 2002}

The aim of this act is to regulate various forms of business restructuring like mergers, alliances, product acquisitions, etc. Chapter II's Sections 5 and 6 of the act deals such business transactions. For instance, in Section 6, the act clearly stated that "no person or enterprise shall enter into a combination that cause or is likely to cause an appreciable adverse effect on competition within the relevant market in India and such a combination shall be void" (Jain, 2012; Ray, 2010; Sansom and Christian, 2010). Prior to this act, the 
Monopolies and Restrictive Trade Practices (MRTP) Act, 1969 was governed monopoly and competition-related issues. In Jain (2012), the author stated that the major issues of the MRTP act were that it had not been accommodated any express provision for the application of anti-competitive conduct outside India but it affects the local market in an adverse manner (p. 116). In fact, the MRTP act had included the Section 23 stating that "companies should concern the government for approval of possible mergers; more positively, this section has been removed in successive reforms mentioning that pre-merger inspection no longer is being required" (Agarwal and Bhattacharjea, 2006, p. 49).

In subsequent amendments, Competition Bill was introduced in the Parliament in 2002 to replace the MRTP act, and thereafter the Competition Act has become a regulation in 2003 under the control of CCI. The act passes the ruling in four areas include anticompetitive agreements, abuse of dominance, combination ruling and competition advocacy. For example, Section 5 of the act provides, what is combination; hence, it has not been defined whether a foreign entity interest comes under the combination, but it stated 'the act is applicable in all combinations' (Jain, 2012; Sansom and Christian, 2010). The act defines a "combination" as any merger, acquisition, or acquiring of control in which the combined assets or turnover of the firms exceeds specified thresholds. According to the new Bill passed in 2007, has suggested that pre-merger notification is necessary, and revised the thresholds to be at least Rs. 5,000 million (about US\$125 million) or Rs. 15,000 million (about US\$375 million), respectively, of the combining parties' joint worldwide assets and turnover would have to be in India. The amendment also notified that "a merger involving a firm with no business in India would still need to be notified if the other party alone has assets or turnover in India exceeding the threshold (Bhattacharjea, 2008, p. 633). The time limit for the CCI initial review has been reduced from 210 days to 180 days whereas the time limit for passing a judgment retained for 210 days. The act sheds some light on cross-border deals and implicitly brings all three types of mergers under its scope and ambit. However, the High Court usually takes at least three to four months to pass an order under Section 394 of the Companies Act, 1956, and additional time required by the CCI, has the effect of rendering Section 31(11) Competition Act, 2002 redundant. In other words, these kinds of discrepancies between various regulations will result in a significant delay in the merger proceedings (Shroff and Ambast, 2013, p. 97). We therefore realize that the act is well written with regard to the anti-competitive measures and the powers of authority, but it has failed to explain any term or definition clearly and interpretative nature. In the recent discussions, CCI has amended few regulations with regard to acquisition approval, which 
include inspect not only the structure of the merger, but also examine the substance of the transaction while approving any merger proposal and no approval is required when a transaction occurs entirely outside India with "insignificant local nexus and effect on markets in India" (Economic Times, 2014a).

\subsection{SEBI (Substantial Acquisition of Shares and Takeovers) Regulations, 1997}

This act is one of influential and straightforward regulations for takeovers and substantial acquisition of shares in India. Prior to this enactment, Clause 40A and 40B under the listing agreement with SEBI usually apply for takeover activities. Following the reforms, SEBI is controlling various takeover deals under the enacted law "SEBI (SAS\&T) Regulations, 1994", which is established under Section 30 of the SEBI Act, 1992 (Ray, 2010). In due course of time, it has appointed a committee headed by the Justice P.N. Bhagawati to review the existing norms prescribed in the act. In 1996, it has approved the recommendations of the committee, and then it has become 'SEBI (SAS\&T) Regulations, 1997', which is a standard code for takeovers. More recently, SEBI further appointed a committee in 2009, headed by C. Achuthan to study and suggest new proposals for improving the 1997 Takeover Code. In a sequence, the committee has submitted a draft report in 2010 and the New Takeover Code 2011 has replaced the existing act. Ray (2010) argued that the term 'Takeover' has not been defined but the term envisages the concept of an acquirer taking over the control or management of the target firm through acquiring substantial acquisition of shares or voting rights. The 1997 takeover code has predominantly been amended roughly 23 times in its 13 years of existence (as cited in Reddy et al., 2011).

\subsection{Income Tax Act, 1961}

Most macroeconomic theories suggested that taxes are important revenue for government to perform various administrative activities, and to implement diverse economic policies as well as to bear those associated costs for a social good (Ezeoha and Ogamba, 2010). Therefore, a country requires an effective authority to carry out such activities. In the Indian institutional environment, tax authorities under the supervision of the Department of Revenue usually administer various rules, regulations, incentives and tax holidays prescribed in the act. It provides tax incentives for amalgamations, merger of banking firms, demerger and slump sale. In particular, Section 2(1B) of the act states, "amalgamation means the combination of one or more companies with an existing company, or the merger of two or more companies to form a new company" (Ray, 2010). According to the provisions mentioned in the act, tax 
authorities have right to impose capital gains tax under transfer of assets in and out of India. For example, the term 'transfer' states, "if merger, amalgamation, demerger or any sort of restructuring results in the transfer of capital assets, it would lead to a taxable event". ${ }^{3}$

\subsection{Foreign Investment Promotion Board (FIPB)}

Following the Parliamentary guidelines in 2003, Board has been transferred to the Department of Economic Affairs, Ministry of Finance. The Board directly coordinates with RBI to facilitate foreign capital flows. It is the important government agency provides single window clearance for FDI in the country. It does not deal with FDI through automatic route. In several policy recommendations, the FDI approval limit has doubled from Rs. 600 crore to Rs. 1200 crore, and more than that maximum limit should approve by the Cabinet Committee on Economic Affairs (CCEA). The e-filing facility is an important initiative of the FIPB to enhance both efficiency and transparency in decision-making. The board has made compulsory to fill "mandatory preliminary application". The FEMA act, 2000 (replacement of the Foreign Exchange Regulation Act, 1973 in 1999) governs trade and foreign exchange market that controlled by the RBI. The objective of the act is to "facilitate external trade and payment and promote orderly development and maintenance of foreign exchange market in India”. According to RBI guidelines, FDI is prohibited under the government route as well as the automatic route in specific sectors include atomic energy, lottery business, business of chit fund, nidhi company, agricultural and plantation activities, housing and real estate business, trading in transferable development rights, and other specified sectors as per the revisions. Hence, the newly elected government has positively reacted in the recent 2014-15 budget proposal with regard to foreign direct investment in various sectors including defense, insurance and retail sectors.

\subsection{Other institutional compliances}

We also found that other industry based regulatory controllers play vital role in both local and international deals relating to direct investments and acquisitions. For instance, Telecom Regulatory Authority of India (TRAI) committee has an authority to recommend direct international investments or foreign mergers in the telecom industry. Likewise, Insurance Regulatory and Development Authority (IRDA) Act, 1999 also monitor the combinations in

\footnotetext{
${ }^{3}$ For instance, "the transfer of assets to the transferee company pursuant to a scheme of amalgamation is not a 'transfer' and does not attract capital gains tax under Section 47(vi) of the Act". Likewise, "a share allotted to shareholders of the transferor company is not a transfer attracting capital gains tax under Section 47(vii) of the Act" (Ray, 2010).
} 
insurance business. Regarding energy sector, Petroleum and Natural Gas Regulatory Board Act, 2006 makes important decisions related to investments, pricing and growth opportunities (Shroff and Ambast, 2013).

The Department of Company Affairs has constituted an expert group for recommending valuation guidelines in the context of corporate assets and shares (Ray, 2010, pp. 647-703). The group observed various matters that require mandatory valuations and those are recommendable to all companies. In sum, most of the above acts have been amended through Finance Act, 2006 and Finance Bill 2012. In accounting view, the Institute of Chartered Accounts of India (ICAI) created a standard on accounting for amalgamations (AS-14).

\section{Indian deals- the dichotomous experience}

A country's regulatory and political environment is imperative for multinational business enterprises when preparing and assessing various investment proposals referring to developing markets as a host. Previous studies in strategy, finance and international business streams suggested that foreign direct investment through acquisition mode is usually influenced by host country's institutions, legal, economic, political and cultural factors (Barbopoulos et al., 2012; Bris et al., 2008; Erel et al., 2012; Feito-Ruiz and MenéndezRequejo, 2011; Ries et al., 2013; Serdar Dinc and Erel, 2013; Zhang and He, 2014, Zhang et al., 2011). In fact, the risk of these institutional dichotomous variables increases when a firm from developed market wants to acquire a firm in developing market (Reddy et al., 2014a). Historically, acquisitions and takeovers are found to be uncommon in emerging markets, but the number, frequency and value of various inorganic strategies (mergers, acquisitions, joint ventures, and private equity investment) have shown a gradual rise in line with policy reforms, especially after 1991. In particular, both inward and outward investments through the acquisition route have seen a momentous growth in the aftermath of the global financial crisis due to lower valuations and easing foreign investment laws. In short, foreign M\&As are found to be a risky investment strategy due to higher levels of control and influence by the host country's risk elements, namely economic, financial, political and legal enforcement.

It is also a fact that Indian institutional laws, mechanism and governance are weak compared to advanced countries and of course, other emerging markets like China and Brazil (Kim and Lu, 2013). Further, there is no coordination between various regulatory authorizes, for example, the existence of an overlap between the CCI and the regulatory authorities leads to the possibility of contradictory decisions which will hinder future deals (Shroff and 
Ambast, 2013, p. 95). In Khanna and Palepu (2000), the authors mentioned that countries like India are facing numerous market regulations, for example, "the financial markets are characterized by inadequate disclosure and weak corporate governance and control ... securities regulations are generally weak and their enforcement is erratic". Similarly, "the nature of coalition politics in the given country, coupled with very activist judicial reviews, means that legislation is a deliberate and erratic process. Moreover, very long delays in the Indian civil procedure mean that the courts have simply been too slow to play a significant role in updating the law, and statutory changes have been slower to implement" (as cited in Armour and Lele, 2008). More importantly, Byington and McGee (2010) mentioned serious comments on white-collar crime (WCC) in India. For example, fraud related to five World Bank health projects that included bid rigging, bribery and manipulated bids during the procurement process; credit card fraud at an Indian call center; and the fraudulent financial statements of the giant outsourcing company Satyam Computer Services, Ltd. Finally yet importantly, both academic and corporate are facing serious problems relating to data accessibility, -collection, and -analysis. Nayyar (2008) described "it is difficult to find complete, let alone systematic, information on cross-border mergers and acquisitions", and the sources of data are disparate as well the information is incomplete".

In particular, a MNC planning to invest in India through FDI or M\&As should also include in their extensive M\&A due diligence efforts a search for WCC (Byington and McGee, 2010). In fact, one would argue that India has become less favored or riskiest locations for investment due to information problems, imperfect contract enforcement, inability to enforce property rights, and flawed regulatory structures (Bhaumik and Selarka, 2012; Byington and McGee, 2010; Khanna and Palepu, 2000; Nayyar, 2008). For instance, Aircel-Maxis deal has been delayed by seven months due to personal involvement of the Ministry of Finance [family members' equity stake in the concerned target entity] (India Today, 2012). Likewise, a few prominent acquisitions were delayed and unsuccessful, and thereby attracted a cosmic public attention due to government intervention, rigid institutional framework and political relations. For example, Bharti Airtel-MTN telecom deal had been failed on the account of dual listing and open offers guidelines. Vedanta-Cairn India energy deal had been delayed for immaterial causes due to open offers and involvement of stateowned enterprise. More importantly, Vodafone had been faced tax plea and other investment arguments in the jurisdiction from 2007 to 2012, wherein, government intended to levy tax on Vodafone-Hutchison telecom deal (Nangia et al., 2011; Reddy et al., 2012, 2014a). To the 
best of our knowledge, Vodafone should be free from tax allegations raised by income tax department.

In the recent 2014-15 budget, government is aimed to allow foreign investment in allied sectors including defense and insurance by offering tax holidays and providing infrastructure facilities. Conversely, it is really a challenging task for M\&A and legal advisory firms when deals are complex nature, for example, Mahindra Satyam and Tech Mahindra merger had been affected due to Satyam's accounting fraud (Financial Times, 2014). Furthermore, business managers and M\&A advisors should assess the efficiency and speed of the judgment in the given host country prior to invest or acquire; for instance, one would notice the dichotomous features of the judicial system when shocked to know that Bhopal gas victims are still waiting for justice since 1984 (MSN, 2013). Nevertheless, this paper intention is not to highlight the reasons behind unsuccessful deals, but rather to provide a set of recommendations for better progress in policy development and implementation referring FDI, M\&As, private equity and venture capitalists.

\section{Policy recommendations}

\subsection{Recommendations for legal framework}

Extant economic and law researchers suggested that a country's economic growth not only depends upon its financial system and financial development, but impinge by its constitutional and legal infrastructure that accountable for good governance. Indeed, both notions play an important role in an economic functioning that transforms the economy from a controlled-setting to an open-economy environment. For instance, the World Bank defined the term governance as- "a power that consists of the traditions and institutions by which authority in a country is exercised. This includes the process by which governments are selected, monitored and replaced; the capacity of the government to effectively formulate and implement sound policies; and the respect of citizens and the state for the institutions that govern economic and social interactions among them". In Licht et al. (2005), the authors mentioned that legal reform is the primary vehicle in the hands of policy makers for peacefully inducing social change. Similarly, sustainable development of a given economy very much depends upon its functioning judiciary, thus government could promise to enforce private property rights that would benefit potential investors (Ramello and Voigt, 2012).

It is worth stating that taxes and penalties are the important sources of revenue for a given economy that would help in implementing various fiscal policies for economic growth; however, it has to govern by the relevant laws, thus there should be reasonable congruence in 
fiscal and legal structures (Ezeoha and Ogamba, 2010). In fact, both national and global welfare maximization requires a cross-border cash-flow tax regime (Becker and Fuest, 2010). In a corporate governance practice, for instance, we support US rulings and others views in favor of shareholders. The President's Advisory Panel on Federal Tax Reform (2005 in Huizinga and Voget, 2009) has advocated the elimination of worldwide taxation by the US economy. The 'best-price' rule under the Securities Exchange Act of 1934 requires that all stockholders be paid the highest consideration to any stockholder in connection with a tender offer (Hao and Howe, 2011, p. 1114). We straightway support the important argument that it is necessary to have an extra-territorial application of domestic competition law to regulate the anti-competitive activities of foreign firms taking place in the given country (Jain, 2012). In particular, we acknowledge the McKinsey proposals for improvement in the existing legal and regulatory framework- "economic and legal framework should make easy fair competition while extenuating the impact of market failures. A fact-based approach and a transparent system are essential for most favorable regulatory decisions. As such, a provision or an act must echo the legal and institutional development; by contrast, adopting international regulations is rarely suitable and can be downright harmful" (Beardsley and Farrell, 2005, p. 50, 58). ${ }^{4}$

The peculiar thing is that "over the past decade, the given economy has received a great deal of foreign capital from various countries and capitalist firms have typically used Singapore or Mauritius established firms to invest in India because of their highly sympathetic tax schemes or treaties" (KPMG, 2012). Further, the most important irregular and controversial issue was that "Ministry of Finance retrospectively illuminated that it has the right to tax the income arising from the country irrespective of where the business is incorporated", which is against the book of law in Vodafone-Hutchison deal (Kanekal and Ganz, 2012). On the other hand, we disagree factually to disclose the essential facts or the loopholes in the given M\&A regulatory system. For instance, when we read M\&A related acts (e.g., Companies Act, 1956; Income Tax Act, 1961; SEBI (SAS\&T) Regulations, 1997), the term 'merger' or 'acquisition' is not defined in the fruitful manner for further reference. Of course, such regulations have used the terms in various sections without appropriate explanation or interpretation. In the land of laws, if any law, regulation or act use any term without defining it properly or meaningfully, such acts are treated as unlawful acts. We

\footnotetext{
${ }^{4}$ In a study of 145 countries, the World Bank found that the administrative cost of complying with regulations is three times higher for businesses in poor countries than for those in rich ones (as cited in Beardsley and Farrell, 2005, p. 50).
} 
strongly argue that why do these acts become perpetual in nature for a social good. Moreover, many of the terms used in other acts to have not explained or interpreted carefully. For instance, Jain (2012, p. 117) mentioned that there should be a clear definition of the term "dominant position" under the Competition Act, 2002. Therefore, government and policy makers should take an immediate call to rewrite and explain the terms that had left in various acts. To do so, there must be a high-level investor protection committee, which should comprise a group of knowledge and experience persona include professionals from the RBI, SEBI, CCI and Registrar of Companies and other responsible departments. The committee must recruit emeritus policy makers from developed economies (e.g. US, UK, Canada, and Germany) as well as senior academic researchers from the field of economics, finance, strategy and law; together achieve better policy making and strong legal enforcement.

In addition, we advise both economic policy makers and regulatory authorities that allowing a tax credit in foreign transactions will let MNCs to make more investment in the same business and other prospect industries in the given host country. For example, Hohler (2013) suggested that the government should establish a policy- "foreign tax payments can be credited against domestic taxes". While allowing the cross listing mode, both local firms and foreign MNCs can better access to international financial markets that result in cheaper external financing (Georgieva and Jandik, 2012). A country that participate in the international trading platform should have well governed and advanced legal systems, accounting standards (e.g. IFRS), security and banking regulations, speedy rebuttal teams to investigate and complete the disputes relating to investment, bankruptcy, shareholder protection and other securities filings. Specifically, better institutional laws reduce the information asymmetry as well as the time required to complete a merger/acquisition legal procedure and legal transaction costs that account for overseas trade and investment transactions (Bris et al., 2008; Reis et al., 2013). In addition, both CCI and Registrar of Companies could create new laws and guidelines with regard to 'spin-offs and the market for corporate control', which would benefit conglomerate firms and other market participants. Indeed, few analysts described that 'spin-offs could set the stage for the next merger wave' (Bloomberg, 2014).

Indian system should adopt better economic governance mechanisms, laws and procedures, effective bankruptcy laws, while showing a strong commitment to the process of financial markets deregulation that enhances the level of active participation in overseas investments in terms of trade, inflows and outflows of FDI and mergers/acquisitions (Athreye and Kapur, 2009). Overall, the reforms will establish a conductive environment for financial 
development that enhances the social living (Beck et al., 2001). While designing policy strategies for a given time, there should be a greater coordination and control between related ministries and service departments. Importantly, one should not freeze 'public power and control' for his (her) own benefit, because that damages both social good and public governance.

\subsection{Recommendations for economic system}

In various years, researchers suggested that there must be needing second-phase economic and financial reforms to strengthen the economy and financial system, and to prepare number of local firms for internationalization (Pandey, 2012). Therefore, the key reforms should focus on foreign investment limits (both inward and outward), private equity laws, investment-banking for financing the mergers, rural banking for improving household savings rate, overseas investments in agriculture and cattle segment for food security, and so forth. In particular, India may offer direct incentives such as, reducing tariffs and quantitative restrictions, tax benefits, and investment subsidies, to attract technological-developed MNCs for establishing sophisticated R\&D facilities. In addition, political leadership will be the critical factor in implementing the second wave of economic reforms, and major efforts shall be required to eliminate (control) the culture of bribery and corruption by imposing a set of penalties and incentives. Altogether, would improve the economic freedom and global competitiveness of the country that will likely persuade other countries to make investments in growing industries include education, retail, and other product-based sectors.

Further, If RBI permits more number of investment banking operations, on one hand, banks would improve deposits, and on the other hand, can raise their investments in startups and large-scale macroeconomic projects (e.g., infrastructure development). Therefore, we strongly believe that bank mergers (both horizontal and vertical) would achieve these goals if RBI, CCI and SEBI shall make necessary amendments in the existing merger guidelines. We recommend SEBI and CCI that valuation and deal disclosure guidelines should incorporate in the subsequent amendments of finance, accounting and capital markets legal frameworks. Importantly, if RBI establishes a special bench with CCI, SEBI and respected service ministries, both overseas and local mergers can be handled quickly that will positively result in the sovereign income.

The bottom line of any economy depends upon its policy administration and plan implementation than a policy-making, and therefore countries like India should contemplate public administration aspects including skill development. In general, banking and financial 
institutional products and services must reach every corner of the country that would bring more savings and investments; as a result, a nation can survive on its own financial backdrop instead of taking external-debt. Eventually, the country will witness a progressive growth in financial markets that certainly helps both domestic and multinational businesses.

\subsection{Recommendations for business managers}

This paper, by and large, suggests important implications for multinational managers with acquiring and target firms in the global and nationals settings. As discussed in the previous section, few Indian deals revealed the impact of institutional distance on cross-border mergers/acquisitions completion involving especially emerging markets. It refers to that institutional dichotomous variable such as weak investor protection, weak financial market regulations, higher levels of political and government intervention and weak legal environment have a negative effect on international inward investments and acquisitions. The time required to complete a merger/acquisition varies with proportionate to the level of legal enforcement, government officials' behavior and degree of ruling party involvement. For example, deals characterize higher valuation, cash payment, acquiring firm with developed country and industry heavily controls by state-owned enterprises have become delay or unsuccessful (Reddy et al., 2014a). In this vein, we postulate that the transaction cost of acquisition increases with proportionate to the (delay) time required to obtain government approvals. While reminding the proverb "look before you leap", multinational mangers participating in an overseas acquisition process should gain better information relating to host country institutional environment, local political party influence, government administration, and economic and financial markets policies and performance. Hence, no comment how do bidding firms acquire better information but one should not solely rely on M\&A advisory firms like investment bankers and legal assistance firms. We also suggest that coordination, network and alliance with project consultants usually help in better understanding the business environment in a host country. In other words, a country's legal environment is a crucial factor for an industry and managers require spending heaps of time managing them carefully.

In Barbopoulos et al. (2012), Erel et al. (2012), and Zhang and He (2014), the authors suggested that "knowledge of the legal system and regulatory provisions, and tax subsidies for international investments or new business ventures is seriously essential for the managers of acquiring enterprises". Importantly, managers should aware local political setting, local government control, bureaucratic administration procedure, home and host country relations, 
trade agreements, and overall global business environment, together build special attention in achieving institutional dichotomous problems (Zhang and He, 2014). Thus, managers must read and understand the legal terminology and relevant laws associated with specific industries prior to establishing their alliances or making acquisitions in countries like India. In fact, we argue that bribe and corruption adversely affect managers' decisions in different international strategies. We argue that lobbying and politicking are being the most influential determinants of MNCs new venture decisions and long-term corporate strategies. In Schöllhammer and Nigh $(1984,1986)$, the authors suggested that "one should not only examine the conflicting political issues within the foreign or host economies, but also study supportive political improvement and changes in intergovernmental dealings". Besides, firms should develop their own strategies to handle a particular situation down the line ranging from application to approval in order to overcome institutional obstacles as well as to hedge cultural difficulties in developing countries like Asian and African continents. Nevertheless, they should choose the best choice of business strategies to tackle the government and to compete with local companies (Scott, 2015). For instance, few scholars suggested that joint ventures, strategic alliances and networks, and other non-equity market entry-modes are being better strategies to offer services in foreign countries when the chosen host country characterizes higher levels of government control, political intervention and corruption, and weak financial markets.

In addition, firms participating first-time in overseas acquisitions should acquire not only relevant knowledge on host country institutional aspects, economic performance and foreign relations, but essential to improve that information through adopting organizational learning models such as learning-by-doing, learning-by-observing and learning-from-others (McConnell, 2014). This experience will have significant impact on subsequent acquisitions in the given country or in other countries. In particular, firm managers should perform indepth analysis addressing issues such as deal structure, payment options, pre-merger planning, due diligence and post-merger integration. Indeed, "effective managers have to see them also as repository opportunities, break down the stereotypes and adapt to an action orientation that promotes learning by doing" (Dhanaraj and Khanna, 2011, p. 698). In sum, one should perceive that successful mergers occur because of many decisions at different levels of management in multinational organizations. 


\subsection{Prospects for businesses and society}

We provide some implications for businesses and society within the M\&A setting. It has been found that international mergers/acquisitions affect the host country human rights for reasons such as physical integrity rights, empowerment rights, workers' rights and women's economic rights, especially in developing markets (Kim and Trumbore, 2010). We postulate that the level of influence on human rights varies with proportion to the amount of inward investment in the given period. Therefore, the government may invite foreign firms to invest in industries that characterize weak financial performance, higher education, medical equipments, hospitalization in rural villages and agricultural equipments and aim at improving the performance of those industries. Similarly, to overcome difficulties in smallscale industries and to create new jobs (besides, saving existing jobs), government may allow certain percentage of FDI through acquisition or alliance that would enhance the performance of such industries and thereby will have greater participation in economic performance of the country. In short, a policy or legal guideline should benefit both businesses in terms of easy doing and society in terms of employment and social security, which will promote entrepreneurship in the given economy. As expressed in previous discussions, easy doing not only depends upon legal and regulatory framework, but also intervenes by ruling political party and corrupted government officials. Therefore, government should stick to better legal systems and efficient control measures that will surely improve overall country performance in global trade and competitiveness.

\section{Conclusions}

Extant literature refers to strategy, international business, finance and sociology suggested that macroeconomic factors such as economic, legal, political, social, cultural and localness influences both inbound and outbound trade, investment and business decisions. While following this streak, the study has presented relevant institutional laws refer to the market for corporate control strategies in India, which include acquisitions, mergers, takeovers, and cross-border deals. The observations include, higher valuation inbound-deals had been delayed or failed due to weak financial infrastructure, erratic nature of government officials and political intervention. Even as opposing this institutional dichotomous behavior, the newly elected government has aimed to be a focus for higher inflow of investment from other developed and emerging markets by easing investment rules and offering tax holidays. The then, it has suggested a set of guidelines for institutional framework in general and multinational managers in particular that advocating foreign direct investment through 
acquisition route. In short, the review and recommendation would help various stakeholders including economists, policy makers, M\&A advisors, legal consultants, investment bankers, multinational managers, private equity firms, and overseas investors and MNCs intending to invest in Indian business. Lastly, this paper has ignored empirical observations with regard to characteristics/financial performance of local and foreign acquisitions in the given country, which left to further research.

\section{References}

Agarwal, M. and Bhattacharjea, A. (2006), "Mergers in India: a response to regulatory shocks", Emerging Markets Finance and Trade, Vol. 42 No. 3, pp. 46-65.

Ahluwalia, M.S. (2002), “Economic reforms in India since 1991: has gradualism worked?", Journal of Economic Perspectives, Vol. 16 No. 3, pp. 67-88.

Akbulut, M.E. and Matsusaka, J.G. (2010), "50+ years of diversification announcements", Financial Review, Vol. 45 No. 2, pp. 231-62.

Alguacil, M., Cuadros, A. and Orts, V. (2011), "Inward FDI and growth: the role of macroeconomic and institutional environment", Journal of Policy Modeling, Vol. 33 No. 3, pp. 481-96.

Armour, J. and Lele, P. (2008), "Law, finance, and politics: the case of India", Working paper no. 107/2008, European Corporate Governance Institute.

Athreye, S. and Kapur, S. (2009), "Introduction: the internationalization of Chinese and Indian firms-trends, motivations and strategy", Industrial and Corporate Change, Vol. 18 No. 2, pp. 209-21.

Banerjee, P., Banerjee, P., De, S., Jindra, J. and Mukhopadhyay, J. (2014), “Acquisition pricing in India during 1995-2011: have Indian acquirers really beaten the odds?", Journal of Banking \& Finance, Vol. 38 No. 1, pp. 14-30.

Barbopoulos, L., Paudyal, K. and Pescetto, G. (2012), "Legal systems and gains from crossborder acquisitions", Journal of Business Research, Vol. 65 No. 9, pp. 1301-12.

Beardsley, S.C. and Farrell, D. (2005), "Regulation that's good for competition", The McKinsey Quarterly, Vol. 2, pp. 49-59.

Beck, T., Demirgüç-Kunt, A. and Levine, R. (2001), “Law, politics, and finance”, available at: http://dev3.cepr.org/meets/wkcn/5/567/papers/levines.pdf (accessed 1 December 2013).

Becker, J. and Fuest, C. (2010), "Taxing foreign profits with international mergers and acquisitions", International Economic Review, Vol. 51 No. 1, pp. 171-86. 
Bhattacharjea, A. (2008), "India's new competition law: a comparative assessment", Journal of Competition Law and Economics, Vol. 4 No. 3, pp. 609-38.

Bhaumik, S.K. and Selarka, E. (2012), "Does ownership concentration improve M\&A outcomes in emerging markets? Evidence from India", Journal of Corporate Finance, Vol. 18 No. 4, pp. 717-26.

Bloomberg (2014), "Spinoffs could set stage for next merger wave: real M\&A", October 15, available at: http://www.bloomberg.com/news/2014-10-14/spinoffs-could-set-stagefor-next-merger-wave-real-m-a.html (accessed 29 October 2014).

Bris, A., Brisley, N. and Cabolis, C. (2008), “Adopting better corporate governance: evidence from cross-border mergers", Journal of Corporate Finance, Vol. 14 No. 3, pp. 22440.

Byington, J.R. and McGee, J.A. (2010), "White-collar crime: a due diligence issue in India", Journal of Corporate Accounting \& Finance, Vol. 21 No. 6, pp. 9-15.

Cheng, H.F., Gutierrez, M., Mahajan, A., Shachmurove, Y. and Shahrokhi, M. (2007), “A future global economy to be built by BRICs," Global Finance Journal, Vol. 18 No. 2 , pp. 143-56.

Czinkota, M.R. and Skuba, C.J. (2014), "Contextual analysis of legal systems and their impact on trade and foreign direct investment", Journal of Business Research, Vol. 67 No. 10, pp. 2207-11.

Dhanaraj, C. and Khanna, T. (2011), "Transforming mental models on emerging markets", Academy of Management Learning \& Education, Vol. 10 No. 4, pp. 684-701.

(The) Economic Times (2014a), "Competition Commission of India tightens rules to see through mergers and acquisition structures", April 2, available at: http://articles.economictimes.indiatimes.com/2014-04-

02/news/48801339_1_competition-commission-transaction-vinod-dhall (accessed 2 April 2014).

(The) Economic Times (2014b), “India’s M\&A deal stands at \$32.6 billion during JanuaryAugust: Grant Thornton", September 18, available at: http://articles.economictimes.indiatimes.com/2014-09-18/news/54067999_1_ma-dealcross-border-deals-equity-deal-activity (accessed 29 October 2014).

Erel, I., Liao, R.C. and Weisbach, M.S. (2012), "Determinants of cross-border mergers and acquisitions", Journal of Finance, Vol. 67 No. 3, pp. 1045-82.

Ezeoha, A.E. and Ogamba, E. (2010), "Corporate tax shield or fraud? Insight from Nigeria”, International Journal of Law and Management, Vol. 52 No. 1, pp. 5-20. 
Feito-Ruiz, I. and Menéndez-Requejo, S. (2011), "Cross-border mergers and acquisitions in different legal environments", International Review of Law and Economics, Vol. 31 No. 3, pp. 169-87.

Financial Times (2014), "Identifying problems before they occur is key when advising on complex M\&A deals", June 11, available at: http://www.ft.com/cms/s/2/c49192b2e733-11e3-88be-00144feabdc0.html\#axzz3HL1sgLfx (accessed 27 January 2014).

Georgieva, D. and Jandik, T. (2012), "Alternative paths of convergence toward U.S. market and legal regulations: cross-listing vs. merging with U.S. bidders", Journal of Multinational Financial Management, Vol. 22 No. 5, pp. 230-51.

Hao, G.Q. and Howe, J.S. (2011), “Does merger structure matter?”, Managerial Finance, Vol. 37 No. 12, pp. 1112-36.

Hohler, K. (2013), “The introduction of the exemption system for foreign profits and its effects on international acquisitions-the UK and Japan regaining international tax competitiveness?", Journal of Applied Accounting Research, Vol. 14 No. 3, pp. 22447.

Huizinga, H. and Voget, J. (2009), "International taxation and the direction and volume of cross-border M\&As", Journal of Finance, Vol. 64 No. 3, pp. 1217-49.

India Today (2012), "Document shows Chidambaram delayed Aircel-Maxis deal by 7 months", May 8, available at: http://indiatoday.intoday.in/story/document-showschidambaram-delayed-aircel-maxis-deal/1/187868.html (accessed 6 February 2014).

Isa, K. (2014), "Tax complexities in the Malaysian corporate tax system: minimise to maximize", International Journal of Law and Management, Vol. 56 No. 1, pp. 50-65.

Jain, A. (2012), "Extra-territorial jurisdiction of Competition Commission of India", Journal of Financial Crime, Vol. 19 No. 1, pp. 112-19.

Kanekal, N. and Ganz, K. (2012), "Vodafone-Hutch deal: retrospective change to I-T Act", available at: http://www.livemint.com/2012/03/16143015/VodafoneHutch-deal-Retrospe.html (accessed 16 September 2012).

Khanna, T. and Palepu, K.G. (2000), "Is group affiliation profitable in emerging markets? An analysis of diversified Indian business groups", Journal of Finance, Vol. 55 No. 2, pp. 867-91.

Kim, D.-H. and Trumbore, P.F. (2010), “Transnational mergers and acquisitions: the impact of FDI on human rights, 1981-2006", Journal of Peace Research, Vol. 47 No. 6, pp. 723-34. 
Kim, E.H. and Lu, Y. (2013), "Corporate governance reforms around the world and crossborder acquisitions", available at http://ssrn.com/abstract=2265263 (accessed 3 December 2013).

KPMG (2012), "What's news in tax: investing in India-the new frontier", available at: http://www.kpmg.com/KY/en/IssuesAndInsights/ArticlesPublications/PublishingImag es/india-new-taxation-regime.pdf (accessed 14 December 2012).

Kumar, N. (2009), "How emerging giants are rewriting the rules of M\&A", Harvard Business Review, Vol. 87 No. 5, pp. 115-21.

Licht, A.N., Goldschmidt, C. and Schwartz, S.H. (2005), "Culture, law, and corporate governance", International Review of Law and Economics, Vol. 25 No. 2, pp. 229-55.

McConnell, L.J. (2014), "Establishing liability for multinational corporations: lessons from Akpan”, International Journal of Law and Management, Vol. 56 No. 2, pp. 88-104.

Meyer, K.E., Estrin, S., Bhaumik, S.K. and Peng, M.W. (2009), "Institutions, resources, and entry strategies in emerging economies”, Strategic Management Journal, Vol. 30 No. 1, pp. 61-80.

MSN (2013), “29 years later, Bhopal gas victims still wait for justice”, December 2, available at: http://news.in.msn.com/national/29-years-later-bhopal-gas-victims-still-wait-forjustice (accessed 4 December 2013).

Nagano, M. and Yuan, Y. (2013), "Cross-border acquisitions in a transition economy: the recent experiences of China and India", Journal of Asian Economics, Vol. 24 No. 1, pp. 66-79.

Nangia, V.K., Agarawal, R., Sharma, V. and Reddy, K.S. (2011), "Conglomerate diversification through cross-continent acquisition: Vedanta weds Cairn India” Emerald Emerging Markets Case Studies, Vol. 1 No. 1, pp. 1-15.

Nayyar, D. (2008), "The Internationalization of firms from India: investment, mergers and acquisitions", Oxford Development Studies, Vol. 36 No. 1, pp. 111-31.

North, D.C. (1990), Institutions, Institutional Change, and Economic Performance, Cambridge University Press, Cambridge and New York.

OECD (2009), "Globalization and emerging economies", Policy Brief, Organisation for Economic Co-operation and Development, available at: http://www.oecd.org/regional/searf2009/42576801.pdf (accessed 5 May 2011).

Pandey, A. (2012), "Policy makers need to revisit prudent approach of the 90s", June 1, The Financial Express, p. 12. 
Ramello, G.B. and Voigt, S. (2012), "Introduction: the economics of efficiency and the judicial system", International Review of Law and Economics, Vol. 32 No. 1, pp. 1-2.

Ray, K.G. (2010), Mergers and Acquisition - Strategy, Valuation and Integration, PHI Learning, New Delhi.

Reddy, K.S., Nangia, V.K. and Agarawal, R. (2011), "Review, rewriting and impact of Indian takeover code", International Journal of Law and Management, Vol. 53 No. 4, pp. 241-51.

Reddy, K.S., Nangia, V.K. and Agrawal, R. (2012), "Mysterious broken cross-country M\&A deal: Bharti Airtel-MTN", Journal of the International Academy for Case Studies, Vol. 18 No. 7, pp. 61-75.

Reddy, K.S., Nangia, V.K. and Agrawal, R. (2013), "Indian economic-policy reforms, bank mergers, and lawful proposals: the ex ante and ex post 'lookup'”, Journal of Policy Modeling, Vol. 35 No. 4, pp. 601-22.

Reddy, K.S., Nangia, V.K. and Agrawal, R. (2014a), "Farmers Fox theory: does a country's weak regulatory system benefit both the acquirer and the target firm? Evidence from Vodafone-Hutchison deal”, International Strategic Management Review, Vol. 2 No. 1, pp. 56-67.

Reddy, K.S., Nangia, V.K. and Agrawal, R. (2014b), “The 2007-2008 global financial crisis, and cross-border mergers and acquisitions: a 26-nation exploratory study", Global Journal of Emerging Market Economies, Vol. 6 No. 3, pp. 257-81.

Reis, N.R., Ferreira, M.P. and Santos, J.C. (2013), "Institutional distance and cross-border mergers and acquisitions completion: a conceptual framework", available at: http://www3.eeg.uminho.pt/economia/nipe/iibc2013/4.2.pdf (accessed 11 December 2013).

Sansom, M. and Christian, P. (2010), "India's new competition regime: the elephant who became a tiger", Journal of European Competition Law and Practice, Vol. 1 No. 1, pp. 62-5.

Schöllhammer, H. and Nigh, D. (1984), "The effect of political events on foreign direct investments by German multinational corporations", Management International Review, Vol. 24 No. 1, pp. 18-40.

Schöllhammer, H. and Nigh, D. (1986), “The effect of political events on Japanese foreign direct investments", Asia Pacific Journal of Management, Vol. 3 No. 3, pp. 133-56.

Scott, C.D. (2015), "Lobbying: a critical dimension of business strategy", International Journal of Law and Management, Vol. 57 No. 1, pp. 17-27. 
Serdar Dinc, I. and Erel, I. (2013), "Economic nationalism in mergers and acquisitions", Journal of Finance, Vol. 68 No. 6, pp. 2471-2514.

Shroff, R. and Ambast, A. (2013), "Ss. 5 and 6 of the Competition Act, 2002: demystifying the competition implications of mergers and acquisitions in India", Journal of Financial Crime, Vol. 20 No. 1, pp. 88-115.

Tan, H.B. and Hooy, C.W. (2003), "Bank merger and bank stock volatility: a postannouncement analysis", Managerial Finance, Vol. 30 No. 4, pp. 29-47.

Varma, S. (2011), "Born global acquirers from Indian IT: an exploratory case study", International Journal of Emerging Markets, Vol. 6 No. 4, pp. 351-68.

World Bank (2014), Doing Business 2015: Going Beyond Efficiency, World Bank, Washington DC.

Zhang, J. and He, X. (2014), "Economic nationalism and foreign acquisition completion: the case of China", International Business Review, Vol. 23 No. 1, pp. 212-27.

Zhang, J., Zhou, C. and Ebbers, H. (2011), "Completion of Chinese overseas acquisitions: institutional perspectives and evidence”, International Business Review, Vol. 20 No. 2, pp. 226-38. 


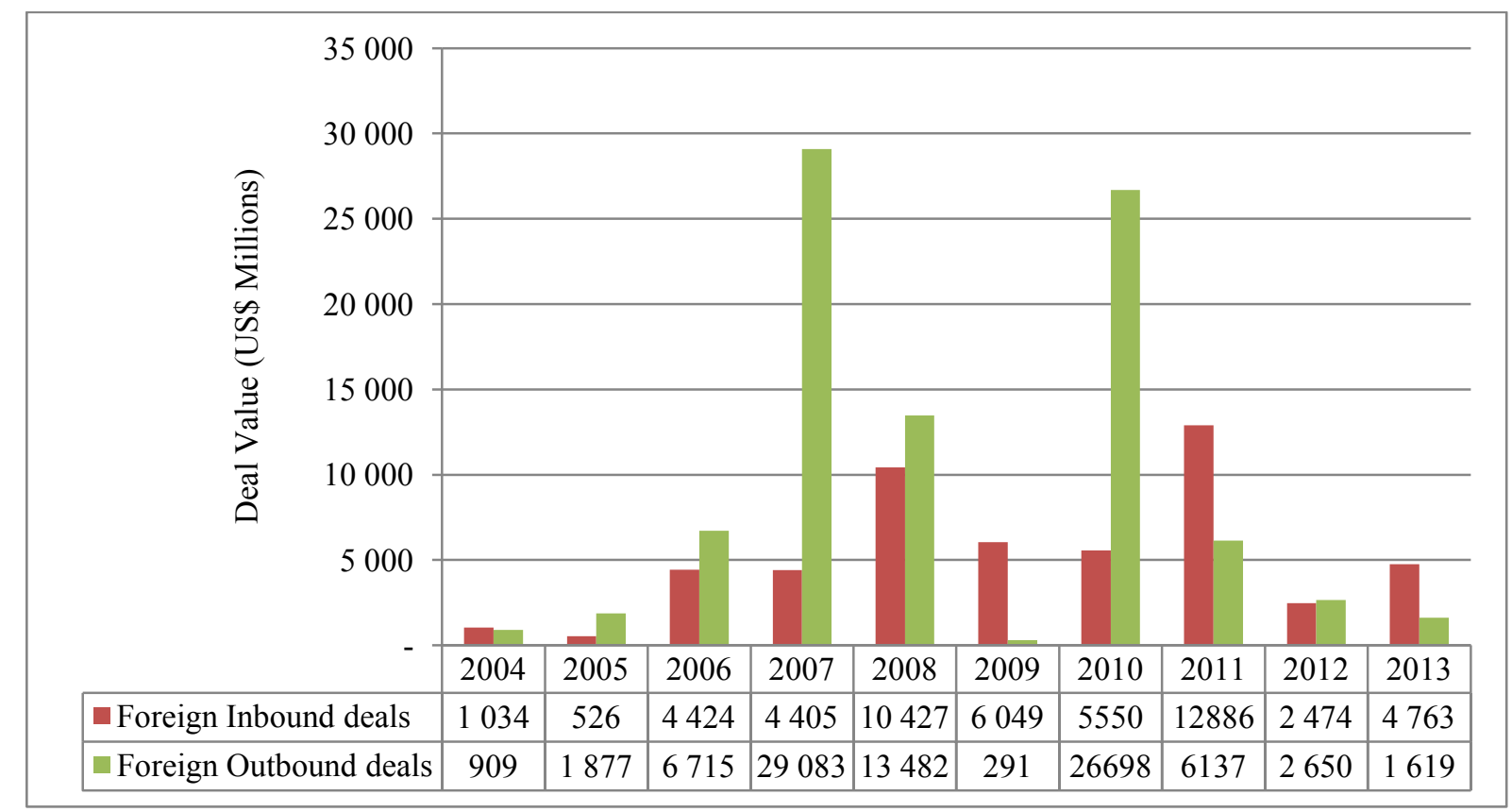

Figure 1. India's foreign inbound and outbound acquisitions, 2004-2013

(source: www.unctad.org) 


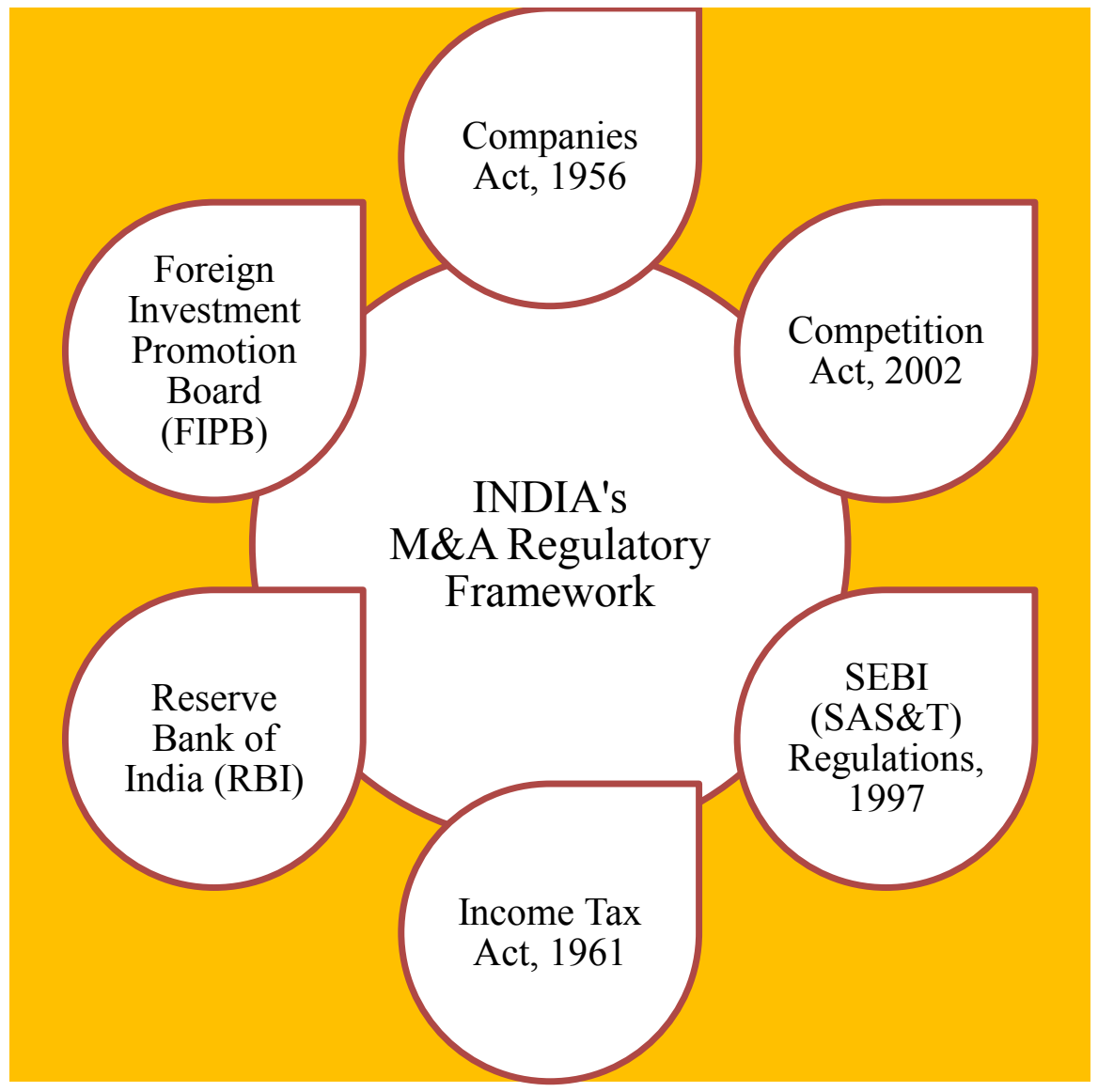

Figure 2. Institutional and M\&A laws in India 